ARTICLE

\title{
Something new under the sun in secondary school: a case study
}

\author{
Silvia Regina dos Santos Coelho ${ }^{a}$ \\ Candido Alberto Gomes ${ }^{b}$
}

\section{Abstract}

This paper reports on a case study carried out in an upper secondary school (grades 10-12), which for 17 years has established learning workshops, with interseriation and interdisciplinarity, as well as complementary distance learning. The establishment, located in the industrial City of Curitiba, Brazil, maintains agreements so that its students, electively, attend the technical education in the counter-term. The qualitative-quantitative methodology included documental analysis, observation, semi-structured interviews with principals, counselors, teachers and students and application of questionnaires to convenience samples of teachers and students. The results show that, according to social expectations, this school has become publicly different due to its methodologies and success in reconciling the preparation for higher studies and technical courses. Continuous assessment and parallel recovery reduce reprobation and abandonment to minimum levels. The predominant organizational image is that of the school as a company, with components of the bureaucratic model, to frame the innovations in the official molds, and the school's image as culture. Implications of these organizational images are discussed.

Keywords: Secondary school. Education policies. Educational project. Teachinglearning processes. School as formal organization.

\section{Introduction}

This paper is part of a broader investigation that aims to bring to the academic debate an innovative educational project to better meet the needs of students and the community, despite a complex, legal and regulatory framework that changes from time to time. The reported case study shows that not only is it possible to innovate, but also to disseminate the after-success experience of a school

\footnotetext{
a Câmara dos Deputados, Brasília, DF, Brasil/Universidade Católica de Brasília, Brasília, DF, Brasil.

b Instituto de Estudos Superiores de Fafe, Fafe, Medelo, Portugal.
} 
network in a relatively populous state before the 2017-2018 secondary school reform, with its contradictions (FERREIRA; RAMOS, 2018). Considering the difficulties of the level of education, with the goals and objectives competing with each other, the SESI CIC Upper Secondary School (grades 10-12), in Curitiba, Paraná, redefined itself in order to meet both the continuity of the studies and the concomitant technical course, preferably in the contiguous technical school of the National Service for Industrial Training (Senai). By observing the student's struggles to find meanings in curricula, compartmentalized in many disciplines, the methodology of the Learning Workshops, created and developed by Rigon (2010), was adopted.

This methodology, also oriented to work and entrepreneurship (not discussed here), is classified as active, in response to the challenges of inter and transdisciplinarity and the students' protagonism. The workshops anticipate a challenge as a starting point, a set of problems that young people need to solve by integrating knowledge, defining strategies, planning processes, learning from mistakes and building new meaningful knowledge. By doing so, the teamwork from students, teachers and counselors is assumed. Thus, the present case study heard and observed students and teachers early on the 2017 school year, when an update of the Pedagogical Proposal was implemented (SESI, 2017). Such characteristics coincide with the Problem-Based Learning (PBL), methodology, also known as Project-Based Learning, which emerged in the 1960s at McMaster University in Canada and in Maastricht, The Netherlands (MORAN, 2013).

The considerations presented in this paper aimed to investigate the Learning Workshop Methodology and how pedagogical strategies of this methodology can improve students' learning and encourage students to stay in secondary school, reducing dropout rates at very low levels, close to zero, while maintaining diversification and educational actions that contribute to making the establishment of a meaningful place for students, where they study individually, but especially in teams. Therefore, it will make them having a greater interaction with teachers, educators and the school management.

\section{Literature fundamentals}

Rivers of ink have been written in Brazil and around the world to discuss secondary education and its implications for social stratification. This is because, after the so-called common school, basilar, secondary level implies a differentiation of ways: to prepare for higher education? Professionalize? Achieve formative goals in themselves? School education, viewed in various paradigms and theories, has contradictory tasks: to democratize and select, to ensure common and diverse 
paths, to homogenize and diversify, as a trunk that opens in branches. Recently, compulsory education in the Northern Hemisphere has extended to about 18 years of age, dilating the waiting time of youth to enter adulthood, given the rarefaction of employment. The school systems that most delay the filtering of students and then distribute them for various careers in secondary school tend to be the most democratizing.

Likewise, the more communication bridges between the branches of secondary education and the lesser existence of alleys in professional education, the greater the equality of opportunities that tends to exist (GOMES, 2016). To inform that the school is in crisis in these circumstances is mere redundancy. In the decline of institutions, with the crisis of modernity, the school distances itself from the lives of its students and its different and heterogeneous social environments. Hence, the lack of meaning of the curricula, in situations where the transmission of encyclopedic content is least expected, leads to boredom, disinterest and annoyance of the young in school (DUBET, 2013; NIZET; HIERNAUX, 1987; PIMENTEL, 2015).

These facts are involved by the more modest results of the schooling on the occupation and the income, since the schooling leaves or reduces its role of social elevator. Consequently, it is not surprising that upper secondary education in Brazil has diminished its attractiveness after the enrollment explosion in the 1990s, and throughout this decade has been continuously reduced (CUNHA, 2018; GOMES; VASCONCELOS; COELHO, 2018; SCHWARTZMAN, 2018).

With a higher bottleneck in the sixth grade of basic school, when the student moves from the classroom teacher to teacher by subject, the age/grade delay changes the frame of personal decisions on the students' front, when searching for progress along the social-educational pyramid. The brilliance of academic courses, leading in principle to higher-level occupations, continues to overshadow large part of the population, as is the case in many countries. The actors of this drama, young people, are located in the center of this labyrinth, seeking a place in the sun, through work and/or continuity of studies, meeting personal and social expectations, dealing with liquefied ethical patterns and seeking elevation of status and income in a country of great social disparity, whose educational pyramid reflects the contours of the sharp social pyramid.

In a legal and normative complex framework, with a plethora of well-intentioned regulations and declarations of values, goals and objectives that, with some difficulty, echo in classrooms, a golden cage syndrome develops in school 
administrators, contrasting the differences in the classrooms resulting from a conflict between what is said in the documents / regulations and the reality of what happens in school. How then can one innovate in establishments and curricula to deal with these critical situations? How to be a high preparatory course for the university admission examination with high results in The National Secondary School Exam (ENEM), not only doing this, but also seeking to overcome the ills of the tradition, a true "square of the circle" (a term used here only as a metaphor, because it presents a great challenge that is difficult to solve) (SANTANA, 2015)?

\section{Methodology}

The nature of this research is classified as an "intrinsic and instrumental case study" (STAKE, 2007), of a qualitative and quantitative nature. From this point of view, documents were included, comprising historical ones; teachers were interviewed; classes and workshops were observed and a questionnaire was applied, with questions predominantly open to a convenience sample of teachers and students. Content analysis was used in transcription texts of semi-structured interviews. The questionnaire applied to teachers consisted of five closed questions that addressed information about age, academic background, teaching time and working time. The four open questions aimed to identify, in the answers given by the teachers, the conceptions and purposes of the evaluation, as well as the most used evaluation instruments and the difficulties they encounter in the act of evaluating. As for the questionnaire applied to students, it had six closed and two open questions.

In all, 16 teachers ( $73 \%$ of the total of 22 ), and 157 students (about $19 \%$ of the total), 26 in the first grade, 49 and 82 in the second and third grades, respectively, answered the questionnaire. The application of the instruments to the students occurred collectively in the classes available, according to the teachers' pedagogical orientation. The answers to the open questions were categorized and tabulated. The concentration of the respondents in the third and second grades was intentional, since they had longer coexistence in the School (COELHO, 2017).

\section{Results and discussion}

The results reveal a mature experience, with the introduction of workshops in 2005 and almost annual reviews, in particular in the research year. The

Square of the circle or quadrature of the circle: a problem in mathematics that consists of finding the side of a square exactly equal in area to a given circular area and that has been shown to be impossible of solution by geometric methods. 
bold innovation core lies in these workshops, which pose as challenges a range of problematic situations for students. It is up to them to choose the problematic situation and the corresponding workshop, in which students, after research, analysis and criticism, will propose alternative solutions, with their pros and cons (for example, a technological change with environmental consequences). Accordingly, they constitute inter-linked teams, while the very nature of challenge involves inter and transdisciplinarity, by the interweaving and integration of conceptual fields of areas and disciplines. Teachers also work in teams $(60 \%$ of their time corresponds to collective work, with students and other teachers). The planning is done through learning routes, using as spaces classrooms, laboratories and library. Bibliographic resources have at least three sources in the same segment and include websites, documentaries, practical and field lessons etc.

Although the establishment is located in the Industrial City of Curitiba (CIC), a peripheral region of the city, receives middle class students (a total of 865 , of which $10.2 \%$ are scholarship holders, divided into 29 classes [average of 29.8 students per class]), and is very strict in its requirements. However, to help and stimulate the students in the teaching and learning process, teachers open opportunities of relaxation, stretching, meditation and ambient music. The curriculum is organized by skills and abilities, with 25 face-to-face classes per week, apart from distance education, whose studies are accompanied by tutor teachers. In addition to the possibility of studying a technical course right next to Senai during the counter-term, only secondary school students can count on media, dance, theater and clubs, according to the "New School Progressivism", a significant trend in Brazil since the 1920's. The creation of clubs refers to the provision of complementary educational and recreational activities through workshops and diversified projects. It is noteworthy that continuous progression is admitted, and in the first week of class, students receive the student guide (SESI, 2013), clarifying procedures and rules; the students also sign a collective coexistence contract. In addition, despite the interdisciplinarity and non-distinction of school grade that make the implementation of the curriculum unique for all grades, the school presents to the authorities a table with the estimated number of class hours per week of each discipline. This official requirement derives from the traditional elitist encyclopaedism for upper class students. Then, the middle level of education was dualistic, in other words, one branch for shaping elites and another one, vocational, for investing in the productive force of workers (CAMPELO, 2017; QUADROS, 2013).

New School Progressivism is a pedagogical movement that began in the late nineteenth century; and it has persisted in various forms to the present. 
With regard to meeting the common national curriculum base - BNCC (BRASIL, 2018), provided for in the Constitution (BRASIL, 1988), the Law of Guidelines and Bases of National Education (BRASIL, 1996), and the National Plan of Education (BRASIL, 2014), the school curriculum consists of 11 items and a diversified part of nine, totaling 20 , with online subjects maintaining the average of 13 quarterly hours. It is possible that such boldness, although "framed" in an official manner, would have even more difficulties of approval if there were not the political and technical weight of SESI and Senai, with their advisors, planners, supervisors, evaluators, etc.

In the 2017 proposal, besides an external evaluation contracted, the school made the student evaluation more complex and detailed, leading teachers, at the beginning of the school year, to a strangeness of the new norms and clamor for bureaucratic overload. The frequency and the evaluation of the use are recorded virtually, in a continuous way. The individual evaluation corresponds to $60 \%$ of the total, involving college entrance examination-style tests (to develop preparatory skills for the exam), with focus on reading, interpretation and writing, and also through reports, diaries and other texts. The group assessment is $40 \%$, focusing on writing and oral skills, through various reports and texts. Teachers prepare and record individual and team assessment maps online, culminating in a quarterly class council without student participation. In this collegiate, teachers evaluate students' school performance by subject according to the curriculum. Learning recovery is parallel, followed, when appropriate, by reevaluation ${ }^{3}$.

Importantly, given the difficulties presented by students entering first grade and the low level of educational instruction, the school instituted the Agile proficiency test, applied at the entrance of first grade and at the exit of third grade of secondary school to identify the main difficulty points presented and to be addressed by all teachers in different subjects. With these data, teachers plan rectification and complementation activities for learning at both individual and group levels. In the face of so much care, it is not surprising that fail rate in 2016 was $3.1 \%$, with a higher value for the first grade (6.2\%) (INEP, 2016a, 2016b). Another positive factor for the school in this period is that there was no student dropout in the three grades. The age distortion to attend secondary school in the appropriate grade, however, was $15.3 \%$ mainly due to previous delays regarding repetition

\footnotetext{
In this perspective, it is noteworthy that to evaluate is an extremely complex act, whose responsibility is not the sole competence of the teacher, but of all the elements of the educational process (students, parents, teachers and staff). It is essential that assessment ceases to be an instrument of classification, selection and social exclusion and becomes a tool for teachers and students committed to the collective construction of a quality school for all (FICHTNER, B. Problemas de avaliação tradicional e perspectivas alternativas. Palestra com Coordenadores, Escolas Públicas do Estado Rio Grande do Sul. 14 de agosto 2013).
} 
in elementary school. Therefore, very important results were verified: despite the rigor the students 'social origins, who tend not to be major heirs of cultural capital, and the fact that they had done previous studies in public and private schools, selectivity was not used for repetition pedagogy.

Conversely, it becomes clear that, based on indicators and day-to-day practices, there is a pedagogy for success to fill the gaps of the previous formation and to recover learning in the measure of the presented difficulties. Parallel recovery, neglected in Brazil since a 1971 Law, does much to reduce the fail rate. Sophistication of evaluative processes, so onerous to teachers, may be countered by the useful record of detailed observations of students' daily lives.

"Giving one in the clove and the other in the horseshoe" is a difficult strategy to establish two objectives expected by students and community: to prepare for the entrance into higher education, predominantly academic, and at the same time, to prepare for the workforce. These have been two functions historically in collision and fulfilled by different schools, academic and vocational, or, respectively, schools for our children and schools for the children of others. In a way, the SESI CIC Upper Secondary School being discussed here predominantly fulfills the academic mission in one or two shifts and the vocational in the counter-term, in agreement with SENAI, resulting in a heavy school workload. For the institution to be chosen by families and young people, it is necessary that it presents publicly high performance in the college entrance examinations and access to higher education. The School, according to students' answers, was chosen by the parents in $44.6 \%$ of the cases and by the students themselves in $33.6 \%$. Students' expectations, reflecting at least in part those of the family, were $40.1 \%$ for admission to higher education and $44.0 \%$ for admission to higher education and preparation for working.

According to the institution's universal data, $51.3 \%$ of enrolled students were paying for high school and vocational-technical education (although dozens of partnerships reduced tuition fees), highlighting the high interest in Senai, while $38.5 \%$ paid just to go to secondary school.

Popular saying: "one in the clove and the other in the horseshoe": the horseshoe is like a "heel" (or "sole"), which is placed on the horse to prevent hoof wear. When the blacksmith is going to put the horseshoe on, he needs to use a clove (a kind of nail) to attach the horseshoe to the hoof to release it. When the blacksmith is going to nail the horseshoe, he usually strikes the hammer with the horseshoe, causing the animal to calm down, because it does not hurt (much) and after a few strokes he gives one to in the clove, which goes into the hoof, pinning the horseshoe. Then he strikes the clove and the hammer in the horseshoe. This makes the animal less aggressive and the work goes out faster. That's why people use the phrase "one in the clove and the other in the horseshoe", which means "to do something good and then something bad". 
Students' answers about what they like most in the School were: first, the methodology (40.1\%); second, teamwork that motivates the formation of social networks of youths (29.3\%); and third, the teachers (24.2\%). Probably, personal and affective aspects are considered here, including teachers' charisma, as emphasized by Dubet (2013).

Undoubtedly, for educators it is hard and demanding to work in a School with so many cross-evaluative visions, inside and outside. However, the School demands mainly continued on-site training, which differs from the model of separate courses and in-house pedagogical support implemented in many public and private school networks. There is much less consultation and collective participation in decisions, and this has seen repeatedly perceived as a failure by many teachers.

In this sense, the decision-making flows are predominantly vertical, from top to bottom, in analogy to an industry, originated in particular in the SESI Regional Department.

The researched School leads a curriculum with a preparatory purpose, effective and legitimized by students, families and the community, that expect that students can access higher education. This is the "beat on the clove", or the role of upper secondary school in the continuity of studies. Beyond this public legitimization, an external contracted evaluation was added in the research year, whose results, towards the end of the school year, were not possible to know. At the same time, the "horseshoe was hit", with a formative education, by preparing for life in general, but also for work. It is noted from previous data that most students enroll in integrated secondary school, double shift, full time, and therefore, experience a very demanding workload. Agreements with Senai are attractive for those whose purchasing power requires that they work and pursue higher education at the same time.

The expected employability, which Senai examines periodically, through panels of employers and educators on the one hand, and by following up graduates on the other hand, is a magnet of reliability for students and their families, according to statements. The opening of vacancies for technical courses by branch and the curricula are planned in Senai through a renowned system of projection of professional needs (BAKULE, 2016), distancing from the call for service or the supposed "social demand". However, the cost of full-time integrated upper secondary school opportunity, possibly exclusive, is quite high and can only be incurred when the student is supported by family income and does not present 
significant age-grade distortion. In fact, this is one of the factors that make it difficult to enter upper secondary education and contribute to vacate the adult education (LIMA; GOMES, 2013).

\section{Final Considerations}

"It's all legal and all very bad". This is a quote from Dr. Anísio Teixeira ${ }^{5}$ that Senator Darcy Ribeiro ${ }^{6}$ used in 1993-1994 with relative frequency during the process of creation of the Education Guidelines and Bases Law (BRAZIL, 1996) in the Senate Education Commission. It meant that, in Brazil, the form matters more than the content, and so does the obedience to the plethora of norms instead of the quality. It is noteworthy that - in the 1930s - Anísio Teixeira was a great educator and one of the main exponents of "New School Progressivism" (CARA, 2016). Darcy Ribeiro was also a pioneer in striving for quality public education, and was vice-director of the then called National institute of Educational Studies. The senator's speeches often quoted that sentence to support a liberating general education law, free from colonialist, bureaucratic mentality. In fact, everything that fits tends to be legal, as long as respects the sacrosanct form. Beyond this reflection, the critique here rests on the partisan political ideological elaborations that structure laws, decrees and public policies - full of popular imagination since Colonial Brazil -, to which Dr. Anísio warned, not by chance that to "do something well done" it is necessary to understand that scientific knowledge has its origin in practical problems, and distances itself from these problems by theoretical abstraction and approaches back to these problems by scientific application (TEIXEIRA, 1965).

It can be said that the case studied here is the opposite of the Anisian refrain as even though the school practices intersectoriality ${ }^{7}$, and interseriation, very striking and typical aspects of the "New School Progressivism, it includes an extensive list of subjects.

Let us, however, deal with the organizational images of the School, according to the classic work of Costa (1999). With the values that underlie its goals and objectives, the SESI CIC School, by "hitting one in the clove and the other in the

\footnotetext{
Anísio Teixeira (1900-1971) was a famous Brazilian educator who led the introduction of the "New School", a pedagogical movement that began in the late nineteenth century that has persisted in various forms to the present.

6 Darcy Ribeiro (1922-1997) was the rapporteur of a new general law on education (1995-1996), in accordance to the new Constitution (BRASIL, 1988).

7 Intersectoriality can be understood as an example of interdisciplinarity. Interdisciplinary work requires the overcoming of the technical action adopted by a multiprofessional team (SANTOS, 2017).
} 
horseshoe", prepares and makes public its success for higher education, that is at the same time formative and vocational. Considering both the administrative structure and the webs of social relations, what are their organizational images, especially after the new pedagogical proposal of 2017 ?

Going through the gallery of Costa (1999), it is clear that there is no a unique "Weberian ideal type" for the SESI CIC Upper Secondary School since this concept is a conception or a pattern of something in its highest perfection, referring to the mental image or conception rather than to a material object. It is a model. Therefore, reality tends to move away from the real. So it's common to find more of an image with which each school identifies itself.

Among other features mentioned above, the School is a self-sustaining company, inserted in the hierarchy of SESI Paraná. It is expected from its principal to be a leader and manager, with other professionals linked to her/him, in the pedagogical and administrative aspects. The internal coherence of the structure is sought, with the intermingling of all and with an ingenious system of evaluation. Revenue and expenses must cover the different cost items, including reinvestment. Productivity and effectiveness are characteristics valued and publicly demonstrated, even by external evaluation. The curriculum is based on the achievement of skills and abilities, many of which attend self-actualization and citizenship, but have a clear north: preparation for work. Following the theories of reproduction, it can be said that the school prepares personnel for capitalist economic activities.

Indeed, we are within this economic system water is to fish. We can criticize it for its many limitations: not only does it change, but also it will become extinct as such sometime in the future. However, young people, as it becomes clear, desire and need to work. They do not belong to leisure or contemplative classes. They need employability to exercise their protagonism and autonomy, goals from their adolescence, and a constant element of their life projects. And for that they need to finance their higher education studies. Moreover, with the evaluation of performance and external assessments, the SESI CIC Upper Secondary School identifies itself with the mechanistic analogy of the machine, having its gears rigorously interwoven, as in an analog clock in church towers and railway stations (symbols of industrial punctuality), according to one of the aspects of Enlightenment and Illustration in modernity.

In this analogy, each person resembles a piece of the machine that must fulfil their role. As a matter of fact, the construction of robots with artificial intelligence is 
the most recent achievement of such an analogy. This type of rationalization refers us to the image of school-business education (although legally without a lucrative function). The 19th century industrial organization is fascinating! However, today's industries, in the post-industrial era, tend to distance themselves more and more from the foundations of the 19th century. The industrially organized school, as an institution, presents lags and offsets and generates malaise among its participants (DUBET, 2013). The contradictions can transform.

On the other hand, in complying with the compulsory regulations of official bureaucracies, the School in focus is approved and solidified as a school of the state system of education, authorized, recognized, evaluated mainly by the quantity of its inputs and issues certificates considered legitimate under normative and legal terms. We have already referred to the formal adjustments in order to comply with the new terms. Then there is a less clear, more elusive but indispensable image of bureaucracy.

However, by opening the supposed black box of conversion processes, and by following the self-image, it was found that there is little room for decision-making participation by the decision-making flows and definitions of the roles of teaching, pedagogical and administrative teams and students. When approaching the company as a more important image, it distances itself from other organizational images of the school, like democracy, political arena or "organized" anarchy. The system is not weakly articulated and much less chaotic. Despite internal contradictions, it seeks to sustain itself internally and externally coherently.

Nevertheless, joint experiences, a relatively long time course (for Brazil) of innovation, accumulated and renewed experiences, by departmental, school and teacher planning in teams, point to the school's image as a culture. In response to the aspirations for the new in the traditional secondary education, the methodology of Rigon's learning workshops (2010) was adopted, with all its structural implications.

From the disruption of traditional teaching methods, the school tried, hit, missed, rectified, ratified, evaluated, and was evaluated several times. Thus, it accumulated a wealth of knowledge and experience in the interaction between theories and practices. This has developed a sense of identity, of us, of sharing. The teachers and the educators know that they work in a different place, with specificities, while the students help to choose a different school, as the community recognizes. Being a student of this school is to be someone who seeks different goals and methodologies. 
The school does not constitute an easy pedagogical way, a pedigree establishment, or a high social class badge. Some students are actually academically rigorous, and others heirs of cultural capital infuriated with the school and perhaps even with society. In the SESI CIC Upper Secondary School those who do not learn, struggle, go back, but rarely miss an entire term. The School prepares for work, yes, but also for the continuity of studies. These are motives conducive to choice and registration: it is different. If the organization involves webs of social relations, such relationships elaborate organized, accumulated and renewed cultural elements. It is, in this case of the school as culture, a culture of its own and publicly distinctive.

Moreover, we can discern yet another organizational image: the political arena, no matter how linear and guided by the Cartesian rationality, is fascinating. In informal relationships, there are leaders, co-leaders and groups that are most often distinguished by symbolic attributes. Although the decision-making participation is reduced, these relations exist. In addition, within the context of schools, SESI, the Federation of State Industries, official bureaucracies and society, there are power relations in overlapping arenas, where the existence and continuity of institutions is determined by their legitimacy, in an untiring process (ALLISON; ZELLIKOW, 1999).

From the axiological point of view, the analogy of the machine and its gears, like the analogical clocks of modernity, constitutes a great attraction, already surpassed by the social sciences. Equally great was the fading of illusions, before the approach of scientific lenses, and the transformations of modernity itself. The analogy above, of high fascination and desire, including the possibilities of reducing unit costs and the possibilities of accumulating profits, contains a serious defect. In the light of science and not of ideology, human and social people are not convertible into objects, although socializing processes try to lead to this. People are willing and have individual characteristics. Above all, education, no matter how standardized it may be, departs from the production of material parts, according to internationally set quality standards.

Education forms such people according to different circumstances, involving, albeit implicitly, values, emotions, attitudes, behaviors, customs and habits. It makes no sense to design school education (just one of the forms of education) according to the input-process-product model and then seek solutions when values of conduct are broken, leading to antisocial behaviors. Or when meaning crises appear, with serious individual and social consequences. Students can be tested with standardized instruments, show knowledge, skills, competencies 
etc., but high performance does not mean that the individual is able to face the challenges of alterity, work and citizenship, for one simple reason: tests measure what they intend to rather than what one has to aspire to measure or "believe" to. A general sense is that there has been far much testing in the school. In this sense, pedagogical leadership is trying to balance assessment, measurement and time for instruction. To recognize that measurement has limits is not to throw it in the trash can, but rather to value it in what scientifically it can do and cannot. However, distorted interpretations, often ideological, with thought charged with desire, seek to use science for what its inevitable limits do not authorize. It is like squeezing the numbers with your hands, even with the most sophisticated statistical treatment: the substance escapes through your fingers, like a child's plastic mass. Reality is more complex than numbers. Creating goals and indicators is a good initiative, of course, quantities are needed, but not enough. So many works have been devoted to unraveling mystifications by statistics.

It is essential to emphasize that it was found that the investigated school meets the official curriculum guidelines according to the national curriculum guidelines and secondary school parameters, also seeking to respond to the challenges of student education for this millennium, spelling out in its pedagogical proposal the four pillars contained in the United Nations Educational, Scientific and Cultural Organization (Unesco) report.

The pillars are: learning to know, learning to do, learning to live together and learning to be (DELORS et al., 1999). The innovative aspect refers to the initiative of interseriation and interdisciplinarity, added to teamwork. This combination allows for greater integration with the concrete reality that the student will encounter in society and promotes the development of awareness of the other's existence and respect for difference.

In summary, throughout the research, it was verified that the processes of curriculum organization, methodologies, times and spaces need to be continuously revised. This is complex, but necessary, since there is a lack of successful pre-proposals for learning in flexible manners in a highly connected society. For that reason, we consider a methodological adjustment of managers and pedagogical team to make modifications in the pedagogical proposal implemented in 2017, since one of the main obstacles of the objective change, standards and curricula of education is historical inertia. Even when the importance of varying skills beyond basic knowledge and skills is verified, it is difficult to effectively introduce new competence and skills into an already established and content-rich system. 


\section{Algo de novo sob o sol no Ensino Médio: um estudo de caso}

\section{Resumo}

O presente artigo relata um estudo de caso realizado numa escola média, que há dezessete anos implantou oficinas de aprendizagem, com interseriação e interdisciplinaridade, bem como o ensino a distância complementar. $O$ estabelecimento, num bairro periférico de Curitiba, Brasil, mantém acordos para que seus alunos, optativamente, cursem o ensino técnico no contraturno. A metodologia, de natureza quali-quantitativa incluiu análise documental, observação, entrevistas semiestruturadas com diretores, orientadores, professores e alunos e aplicação de questionários a amostras de conveniência de docentes e discentes. Os resultados evidenciam que, atendendo às expectativas sociais, a Escola investigada se tornou publicamente diferente pelas suas metodologias e pelo êxito ao conciliar a preparação para os estudos superiores e o curso técnico. A avaliação contínua e a recuperação paralela reduzem a reprovação e o abandono a níveis mínimos. A imagem organizacional predominante é a da escola como empresa, com componentes do modelo burocrático, para enquadrar as inovações nos moldes oficiais, e a imagem da escola como cultura. Discutem-se implicações destas imagens organizacionais.

Palavras-chave: Ensino médio. Política educacional. Projeto educacional. Ensinoaprendizagem. Escola como organização formal.

\section{Algo nuevo bajo el sol en la Educación Secundaria: un estudio de caso}

\section{Resumen}

Este estudio de caso se centra en una escuela secundaria superior (grados 10-12) que adoptó hace 17 años talleres de aprendizaje, interdisciplinaridad, integración entre grados y educación a distancia complementaria. Esta unidad, ubicada en la Ciudad Industrial de Curitiba, Brasil, estableció acuerdos para viabilizar la matrícula de sus estudiantes también en la educación técnica. Esta investigación cualitativa-cuantitativa se basó en análisis documental, observación, entrevistas semiestructuradas con directivos, orientadores, profesores y estudiantes y cuestionarios aplicados a docentes y discentes. Los resultados evidencian que, de acuerdo con las expectativas sociales, esta escuela es conocida por sus metodologías, así como por el suceso en su doble rol, preparando para el ingreso en la educación superior y en la formación técnica. La evaluación formativa y los estudios paralelos de recuperación del aprendizaje han reducido la repetición y el abandono a niveles mínimos. La imagen organizacional predominante es de la escuela como empresa, asociada a características de tipo burocrático, con el fin de "encuadrar" las innovaciones a los modelos oficiales, así como de tipo escuela como cultura. Este trabajo discute implicaciones de estas imágenes organizacionales.

Palabras clave: Educación secundaria. Politicas educativas. Proyecto educativo. Enseñanza-aprendizaje. Escuela como organización formal. 


\section{References}

ALLISON, G.; ZELIKOW, P. Essence of decision: explaining the Cuban missile crisis. 2. ed. New York: Longman, 1999.

BAKULE, M. et al. Developing skills foresights, scenarios and forecasts: guide to anticipating and matching skills and jobs, Luxemburgo: Publications Office of the European Union, 2016. v. 2.

BRASIL. Lei n ${ }^{\circ}$ 9.394, de 20 de dezembro de 1996. Estabelece as diretrizes e bases da educação nacional. Diário Oficial da União, Brasília, DF, 23 dez. 1996.

BRASIL. Lei $\mathrm{n}^{\circ} 13.005$, de 25 de junho de 2014. Aprova o Plano Nacional de Educação - PNE e dá outras providências. Diário Oficial da União, Brasília, DF, 26 jun. 2014.

BRASIL. Ministério da Educação. Conselho Nacional de Educação. Base Nacional Comum Curricular (BNCC): educação é a base: ensino médio. Brasília, DF, 2018.

BRASIL. Senado Federal. Constituição da República Federativa do Brasil. Brasília, DF: Senado Federal, 1988.

CAMPELO, C. L. F. Reforma Capanema e Reforma Mendonça Filho: primeiras aproximações. In: JORNADA INTERNACIONAL POLÍTICAS PÚBLICAS, 8., São Luiz, 2017. Anais [...]. São Luís: UFMA, 2017. Disponível em: http:// www.joinpp.ufma.br/jornadas/joinpp2017/pdfs/eixo13/reformacapanemaerefor mamendoncafilhoprimeirasaproximacoes.pdf. Acesso em: 9 jan. 2019.

CARA, D. Perfil: o criador da Escola Nova: Anísio Teixeira. Desafios do Desenvolvimento, v. 12, n. 86, 2016. Disponível em: http://www.ipea.gov.br/ desafios/index.php?option $=$ com_content\&view $=$ article $\&$ id $=3246 \&$ catid $=30 \& I$ temid=41 . Acesso em: 8 jan. 2019.

COELHO, S. R. S. Gestão pedagógica do ensino médio: estudo de caso sobre uma metodologia inovadora na cidade de Curitiba - PR. 2017. Tese (Doutorado em Educação) - Universidade Católica de Brasília, Brasília, DF, 2017.

COSTA, J. A. Imagens organizacionais da escola. 5. ed. Porto: Asa, 1999.

CUNHA, C. Ensino médio no Brasil: evolução de ideias, propostas e perspectivas. In: GOMES, C. A; VASCONCELOS, I. C. O.; COELHO, S. R. S (orgs.). Ensino médio: impasses e dilemas. Brasília, DF: Sociedade Brasileira de Educação Comparada-UNESCO, 2018. p. 79-114. 
DELORS, J. et al. Educação um tesouro a descobrir: relatório para a UNESCO da Comissão Internacional sobre Educação para o Século XX. Brasília, DF: Cortez, 1999.

DUBET, F. El declive de la institución: profesiones, sujetos e individuos en la modernidad. Barcelona: Gedisa, 2013.

FERREIRA, R. A; RAMOS, L. O. L. O projeto da MP n ${ }^{\circ}$ 746: entre o discurso e o percurso de um novo ensino médio. Ensaio: Avaliação e Políticas Públicas em Educação, Rio de Janeiro, v. 26, n. 101, p. 1169-1175, out./dez. 2018. https://doi.org/10.1590/s0104-40362018002601295

GOMES, C. A. Diálogos com quem faz: tendências da educação profissional em países participantes da Worldskills 2015. Brasília, DF: Senai, 2016.

GOMES, C. A.; VASCONCELOS, I. C. O.; COELHO, S. R. S. (orgs.). Ensino médio: impasses e dilemas. Brasília, DF: Sociedade Brasileira de Educação Comparada: Unesco, 2018.

INSTITUTO NACIONAL DE ESTUDOS E PESQUISAS EDUCACIONAIS ANÍSIO TEIXEIRA - INEP. Censo escolar de 2015: colégio SESI - CIC ensino fundamental e médio: distorção idade - série 2007 a 2016. Brasília, DF, $2016 \mathrm{a}$.

INSTITUTO NACIONAL DE ESTUDOS E PESQUISAS EDUCACIONAIS ANÍSIO TEIXEIRA - INEP. Censo escolar de 2016: colégio SESI - CIC ensino fundamental e médio: taxa de rendimento por etapa escolar. Brasília, DF, 2016b.

MORAN, J. M. Metodologias ativas para uma aprendizagem mais profunda. São Paulo: ECA/USP, 2013.

NIZET, J.; HIERNAUX, J.-P. O aborrecimento dos jovens na escola. Porto: Rés, 1987.

PIMENTEL, G. S. R. Ensino médio: contradições conceituais. Curitiba: CRV, 2015.

QUADROS, R. S. Gustavo Capanema: a organização do ensino primário brasileiro no período de 1934-1945. Maringá, 2013. Dissertação (Mestrado em Educação) - Centro de Ciências Humanas, Letras e Artes. Universidade Estadual de Maringá, Maringá, 2013.

RIGON, M. C. Prazer em aprender: o novo jeito da escola. Curitiba: Kairós, 2010. 
SANTANA, E. R. O problema da quadratura do círculo: uma abordagem histórica sob a perspectiva atual. Manaus, 2015. Dissertação (Mestrado em Matemática) Instituto de Ciências Exatas, Universidade Federal do Amazonas, Manaus, 2015.

SANTOS, E. F. O desafio da intersetorialidade entre educação e assistência social: Escola Vila Esperança, CRAS Espaço Esperança e Grupo Primavera - Campinas/SP. Americana, 2017. Dissertação (Mestrado em Educação) Centro Universitário Salesiano de São Paulo Unisal, São Paulo, 2017.

SCHWARTZMAN, S. O novo ensino médio: o difícil caminho à frente. In: GOMES, C. A.; VASCONCELOS, I. C. O.; COELHO, S. R. S. (orgs.). Ensino médio: impasses e dilemas. Brasília, DF: Sociedade Brasileira de Educação Comparada: Unesco, 2018. p. 15-35.

SERVIÇO SOCIAL DA INDÚSTRIA - SESI. Departamento Regional do Paraná. Proposta pedagógica do ensino médio. Curitiba, 2017.

SERVIÇO SOCIAL DA INDÚSTRIA - SESI. Departamento Regional do Paraná. Guia do aluno. Curitiba: SESI/PR, 2013. Disponível em: http:// www.sesipr.org.br/colegiosesi/uploadAddress/GUIA_DO_ALUNO_ COMPLETO[41663].PDF Acesso em: 8 jan. 2019.

STAKE, R. E. A arte de investigação com estudos de caso. Lisboa: Fundação Calouste Gulbenkian, 2007.

TEIXEIRA, A. Gilberto Freyre, mestre e criador de sociologia. Revista Brasileira de Estudos Pedagógicos, Brasília, DF, v. 40, n. 91, p. 29-36, jul./set.1965.

\section{Informações dos autores}

Silvia Regina dos Santos Coelho: Analista Legislativo na Câmara dos Deputados, Brasília. Doutora em Educação e Mestre em Comunicação pela Universidade Católica de Brasília. Contato: silvia.coelho@camara.leg.br

iD http://www.orcid.org/0000-0002-5102-442X

Candido Alberto Gomes: Professor Catedrático na área de Educação do Instituto de Estudos Superiores de Fafe, Portugal. Ph.D. em Educação pela Universidade da Califórnia, USA. Fundador e catedrático honorário da Cátedra Unesco de Juventude, Educação e Sociedade, Brasil. Contato: candidoacg@gmail.com

iD http://www.orcid.org/0000-0001-8498-3785 